NOTE

\title{
Turbellarian black spot disease in bluespine unicornfish Naso unicornis in New Caledonia, caused by the parasitic turbellarian Piscinquilinus sp.
}

\author{
Jean-Lou Justine ${ }^{1, *}$, Philippe Leblanc ${ }^{2}$, Florent Keller ${ }^{2}$, Robert J. G. Lester ${ }^{3}$ \\ ${ }^{1}$ Équipe Biogéographie Marine Tropicale, Unité Systématique, Adaptation, Évolution (CNRS, UPMC, MNHN, IRD), \\ Institut de Recherche pour le Développement, BP A5, 98848 Nouméa Cedex, New Caledonia \\ ${ }^{2}$ Aquarium des Lagons, BP 8185, 98807 Nouméa, New Caledonia \\ ${ }^{3}$ Parasitology, SCBS, The University of Queensland, Brisbane, Queensland 4072, Australia
}

\begin{abstract}
Turbellarian black spot disease is described in a bluespine unicornfish Naso unicornis (Perciformes, Acanthuridae) collected from the wild off Nouméa, New Caledonia, South Pacific. Each cyst contained a whitish worm, 2 to $4 \mathrm{~mm}$ in length, which was able to swim freely in seawater. Cyst walls consisted of fibrous tissue with a scattering of melanocytes. Worms had 2 eyespots at the anterior end, a pharynx at the posterior end and a largely undeveloped reproductive system. They were identified as Piscinquilinus sp. (= Ichthyophaga sp.), a genostomatid turbellarian. The disease spread within 2 wk from a single infected fish to 3 other unicornfish in the same tank, in spite of copper sulphate and diluted seawater treatment; however, other fish from several families kept in the same tank were not infected, suggesting specificity of these parasites. Praziquantel injections into the infected fish eliminated the infection. Other cases of turbellarian infections are reported from 7 fish species off New Caledonia; prevalence is very low $(0.3 \%)$.
\end{abstract}

KEY WORDS: Black spot disease · Fish $\cdot$ Naso unicornis $\cdot$ Turbellaria $\cdot$ New Caledonia $\cdot$ Piscinquilinus · Ichthyophaga

\section{INTRODUCTION}

The Turbellaria generally differ from the parasitic flatworms (or Neodermata) by their free-living (nonparasitic) life. However, a few species are parasitic and parasitise marine invertebrates such as molluscs and some fish species (Cannon 1986). In tropical fish, species from 2 genera, Paravortex and Piscinquilinus, are known to produce 'black spot disease' (Cannon \& Lester 1988).

The unicorn tang or bluespine unicornfish Naso unicornis is abundant in the lagoon of New Caledonia. It is very common at fish markets (where it is sold under the local name of 'dawa'), is particularly prized as food, and has a good reputation of being devoid of ciguatera-poisoning. The black spot disease described here concerned aquarium fish, but there is no doubt that the appearance of the infected fish would have a negative impact on sales, since unicornfish are sold whole.

In this paper, we describe the external aspect of turbellarian black spot disease in wild specimens of unicornfish caught for aquarium purposes, report the treatment used to try to cure the disease, and explain how the parasite could be identified. In addition, records of similar turbellarian parasites found in wild fish from New Caledonia are reported.

\section{MATERIALS AND METHODS}

Fish were caught by divers at night with nets at Récif Larégnère off Nouméa, New Caledonia (22 April 2008, 
$22^{\circ} 19^{\prime} 50^{\prime \prime} \mathrm{S}, 166^{\circ} 18^{\prime} 35^{\prime \prime} \mathrm{E}$ ), for inclusion in the aquarium. In addition to 4 bluespine unicornfish Naso unicornis (Acanthuridae; fork length 400 to $500 \mathrm{~mm}$ ), other species included 2 Heniochus chrysostomus (Chaetodontidae), $1 \mathrm{H}$. varius, 1 Chaetodon auriga (Chaetodontidae), 1 Parupeneus indicus (Mullidae), 1 P. multifasciatus, 1 Gymnothorax sp. (Muraenidae), 1 Scarus sp. (Scaridae), 1 Forcipiger flavissimus (Chaetodontidae) and 1 Caesio caerulaurea (Caesionidae). All fish were transferred to a $2500 \mathrm{l}$ tank for examination and quarantine before being introduced into the display tank. Black spots were noticed on one fish, and a treatment was applied (see 'Results').

Tissue containing 2 black cysts was excised and fixed in Bouin's fixative. It was later embedded in wax, sectioned at $5 \mu \mathrm{m}$ and stained with haematoxylineosin. Whole worms and histological sections were deposited in the Muséum national d'histoire naturelle (MNHN), Paris, France, ref. JNC2556 and the Queensland Museum, Brisbane, Australia, cat. nos. G231341-231344.

\section{RESULTS}

Progression of the disease and treatment. On Day 1 (23 April 2008), black spots were noticed on 1 unicornfish (out of 4). Other fish were not infected. From Day 1 to Day 7, all fish, including the 4 unicornfish, were routinely kept in a closed-circuit $2500 \mathrm{l}$ tank with $15 \mathrm{mg} \mathrm{l}^{-1}$ copper sulphate and diluted seawater (density 1020) at a temperature of $28^{\circ} \mathrm{C}$. This is the routine quarantine method used in the Nouméa aquarium. On Day 7 , black spots were noticed on a second unicornfish. All other fish species appeared healthy and were separated from the unicornfish for further inclusion in the display tanks. From Day 7 to Day 17, the 4 unicornfish were kept in the same closed-circuit tank with copper sulphate and diluted seawater. On Day 17, the 4 unicornfish were transferred to an open-circuit tank in plain seawater. They were injected with Praziquantel (Droncit, 0.2 to $0.4 \mathrm{ml} \mathrm{fish}^{-1}$, i.e. $17 \mathrm{mg}$ Praziquantel $\mathrm{fish}^{-1}$ ). On Day 26, all 4 unicornfish displayed black spots. One individual was collected for further parasitological study. On Day 32, the 3 remaining unicornfish were again injected with Praziquantel (17 mg fish ${ }^{-1}$ ). From Day 32 to Day 60, black spots diminished progressively and eventually vanished. The 3 unicornfish were finally released.

Parasitological examination of 1 fish. The unicornfish collected on Day 26 was photographed on both sides (Fig. 1A,B). About 20 black spots were counted. The black spots appeared as swellings, 2 to $4 \mathrm{~mm}$ in diameter, and no opening was visible. No parasite was visible from the outside (Fig. 1C). When gently opened with the fine point of a Dumont pincer and delicately pressed, each black spot produced a single worm, 2 to $4 \mathrm{~mm}$ in length (Fig. 1D). The worms were whitish or yellowish, probably showing different states of maturation; they were able to swim actively in seawater, and eyes were visible at the anterior end. Further microscopic examination of living parasites in seawater between a slide and a cover slip failed because the worms were sensitive to pressure and exploded, leaving no identifiable elements.

Microscopic examination of preserved parasites. Preserved cysts contained a single worm. In histological sections, eyes were distinguished at 1 end of the worm (Fig. 1E) and a pharynx at the other (Fig. 1F), ascertaining that the parasites belongs to the genus Piscinquilinus (Platyhelminthes, Prolecithophora, Genostomatidae Von Graff, 1903). The centre of the worm contained cells resembling host leucocytes. Around this mass were numerous multinucleate cells possibly associated with intracellular digestion. Outside of this was a layer of refractile non-staining granular cells interspersed with occasional large eosinophilic cells. The rhabdite/ciliary layers appeared fused and formed a dense basophilic layer around the worms. In 1 specimen, a small area of glandular tissue and what appeared to be spermatogonia occurred in the granular layer.

The cyst wall consisted of a thick layer of fibrous tissue within which were capillaries and scattered melanocytes (Fig. 1E). At the end of 1 cyst opposite the pharynx was a developing granuloma with leucocytes and erythrocytes similar to the cell mass in the gut of the worm. In the second specimen, a large area of dying cells was observed at 1 end of the cyst and near the surface of the fish (Fig. 1G). This was adjacent to an area of fluid accumulation within the cyst. Some host cell debris was inside the cyst wall at this point, suggesting that the cyst wall had been perforated.

Records of similar turbellarians in other wild fish. In New Caledonia, more than 2500 wild coral reef fish belonging to 270 species were examined by J.-L. Justine during a 6 yr period (2003 to 2008). Only 7 cases of turbellarian parasite infections were noticed (Table 1), each time with a single case in 7 species of fish. General prevalence was $0.3 \%$ (7/2500). Parasites reported in Table 1 were not processed for microscopy, and it was not determined whether they belonged to Paravortex or Piscinquilinus.

Among 18 specimens of Naso unicornis taken from the wild (2003 to 2008) and examined, none was infected. Among the hundreds of fish examined at the Nouméa aquarium, black spot disease was not noticed before the unicornfish mentioned in this study. 

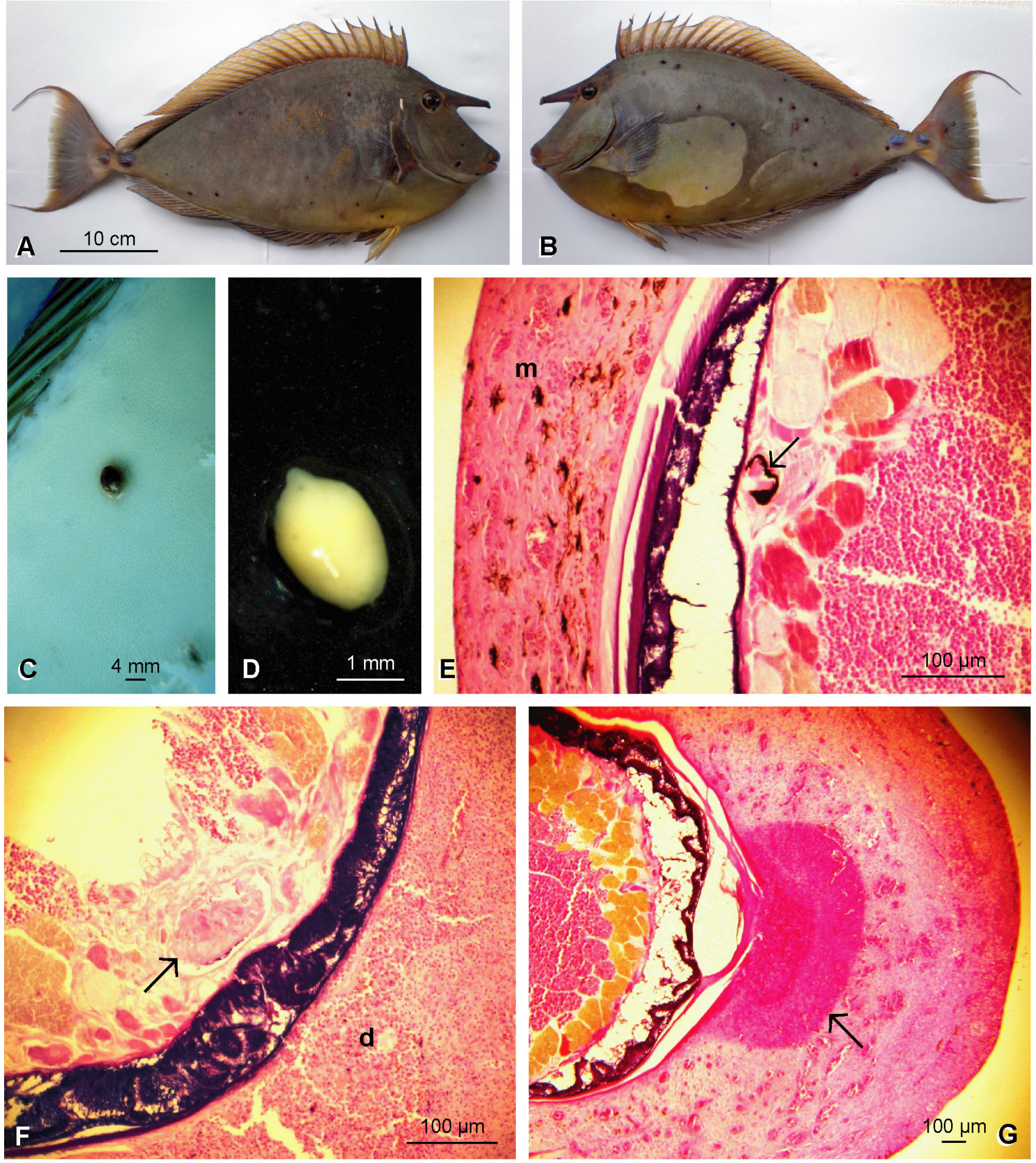

Fig. 1. Naso unicornis and Piscinquilinus sp. (A,B) Bluespine unicornfish infected with black spot disease. Photographs of both sides of the dead fish; the discoloured area in the centre of the fish in (B) is an artefact due to wet skin. (C) Black spot on the skin. (D) Live turbellarian, Piscinquilinus sp., extracted from a cyst and swimming in seawater. (E-G) Piscinquilinus sp. in skin of N. unicornis, haematoxylin-eosin section. (E) Arrow: eye-spot; m: melanophore. (F) Arrow: pharynx; d: developing granuloma with free erythrocytes and leucocytes. (G) Margin of cyst showing region of dying host cells (arrow). Scale bars in (C,D) 
Table 1. Turbellarian parasites found in coral reef fishes off Nouméa, New Caledonia. These are the only cases of turbellarian parasite infections among more than 2500 fish examined from 2003 to 2008

\begin{tabular}{|llllc|}
\hline Family & Species & Organ & Date found & Prevalence \\
\hline Acanthuridae & Acanthurus xanthopterus & Skin & May 2003 & $1 / 4$ \\
Chaetodontidae & Chaetodon ephippium & Skin & May 2003 & $1 / 2$ \\
Labridae & Cheilinus chlorourus & Gills & March 2003 & $1 / 6$ \\
& Thalassoma lutescens & Skin, fins, gills & February 2003 & $1 / 7$ \\
Nemipteridae & Nemipterus furcosus & Gills & November 2007 & $1 / 200$ \\
Pomacentridae & Chromis viridis & Fins & May 2006 & $1 / 9$ \\
Serranidae & Epinephelus fasciatus & Skin & June 2003 & $1 / 100$ \\
\hline
\end{tabular}

\section{DISCUSSION}

Black spot diseases in fish have been attributed to metacercariae (Möller \& Anders 1986, Shukhgalter \& Chukalova 2002, Ondrackova et al. 2004, Quist et al. 2007) and turbellarians (Cannon \& Lester 1988). Turbellaria can be distinguished from metacercariae after releasing them from the cyst by their mechanism of movement. Turbellaria have cilia on the surface on which they glide, whereas metacercariae are devoid of cilia and generally move by peristalsis. Of the turbellarians from fish, Paravortex species have eyes and pharynx in the anterior of the body, whereas Piscinquilinus have anterior eyes and a posterior pharynx (Cannon \& Lester 1988).

The closely related turbellarians Piscinquilinus and Urastoma are symbiotic worms, and Urastoma is found in molluscs and Piscinquilinus in fish (Cannon 1986). Urastoma species possess a muscular penis bulb, a feature absent from Piscinquilinus and from our specimens.

The genus Piscinquilinus currently contains the single species P. subcutaneus (Syromiatnikova 1949) Sluys \& Kawakatsu, 2005. Piscinquilinus (Sluys \& Kawakatsu 2005) is a replacement name for Ichthyophaga Syromiatnikova, 1949, preoccupied by a bird. Piscinquilinus (as Ichthyophaga) was classified within the Prolecithophora by Cannon (1986), but molecular analyses by Lockyer et al. (2003) suggested a phylogenetic position within a sister-group to the Neodermata (the 'true' parasitic Platyhelminthes). Further molecular analyses are needed to distinguish species of Piscinquilinus, not least on account of the poorly defined reproductive structures of what appear to be essentially immature worms when they are in fish.

Piscinquilinus subcutaneus was described from within the skin and fins of 2 benthic temperate water fishes, the cottid Bero elegans and the greenling Hexagrammos decagrammus, both taken in the Ussurian Gulf east of Vladivostok (latitude $44^{\circ} \mathrm{N}$ ) (Syromiatnikova 1949). Later, Menitskii (1963) gave a detailed description of what he thought was the same worm, though much smaller $(0.35-0.5 \mathrm{~mm}$ versus up to $4.4 \mathrm{~mm})$, from the gills of the tropical serranid Cephalopholis pachycentron (a junior synonym of $C$. boenak; locality unstated). Our worms were of a similar size to that reported in the original description but were whitish rather than brick red and were collected in the tropics (latitude $22^{\circ} \mathrm{S}$ ).

There are no previous records of Turbellaria from New Caledonia (Justine 2007). Thus, all turbellarian infections reported in Table 1 are new records for New Caledonia, as is the Naso unicornis infection. Infections with parasitic turbellarians seem to be rare in coral fish taken from the wild: our results in New Caledonia show that their prevalence was less than $0.3 \%$. On the Great Barrier Reef, turbellarians were rarely seen at Heron Island in the south but were occasionally found at Lizard Island in the north (Grutter 1994). Those found were pale and less than $1.3 \mathrm{~mm}$ long (Cannon \& Lester 1988, Grutter 1994) suggesting that they were different species from Piscinquilinus subcutaneus or the one we found in New Caledonia.

Parasitic turbellarians of fish such as Paravortex and Piscinquilinus spp. are believed to have a single host life-cycle. Paravortex spp. are viviparous and produce many juveniles (Cannon \& Lester 1988), the life cycle of 1 species being completed within $10 \mathrm{~d}$ (Kent \& Olson 1986). This ensures rapid spreading of the disease within a confined volume of sea water. Piscinquilinus spp. may not be viviparous and may have a longer life cycle. Our specimens remained on the fish for at least 30 d. The cyst wall laid down by the fish became a thick organised layer of fibrous tissue and capillaries, very different from the temporary epidermal pockets described for Paravortex spp. (Kent 1981, Cannon \& Lester 1988). The lack of well developed reproductive organs in the worm suggests that maturation only occurs after the worm has left the fish. This is consistent with the apparent break in the cyst wall shown in Fig. 1G and the observation that of 5 melanised cysts dissected by Cannon \& Lester (1988) only 3 contained a turbellarian; the others were empty. Once away from the fish, the worms presumably produce a cocoon 
within which they reproduce, as has been described for the closely related Urastoma cyprinae by Crespo Gonzalez et al. (2005).

Although some turbellarian species such as Paravortex sp. infest a wide variety of fishes (Kent \& Olson 1986), Piscinquilinus species may be more host specific. Our infected unicornfish was kept in a tank with several species of fish and the disease was apparently transmitted only to fish of the same species, although fish belonging to families such as scarids are known to be sensitive to Piscinquilinus infections (Cannon \& Lester 1988). This apparent specificity suggests that several cryptic Piscinquilinus species, each relatively specific, could be present in natural conditions, rather than a single generalist species.

Turbellarian diseases have implications for the health of ornamental fishes and the quality of aquarium displays, because the black spots are aesthetically unappealing and can be easily noticed by the public. It also has negative implications for the health of cultured fish and their economic value.

A $17 \mathrm{~d}$ treatment with copper and diluted seawater did not cure the infected fish and apparently did not stop the infection being transmitted to other fish. The treatment with Praziquantel was associated with the decline of the infection only after 2 injections. Praziquantel has already been demonstrated to be effective against monogenean parasites (e.g. Schmahl \& Mehlhorn 1985, Fajer-Avila et al. 2007, Williams et al. 2007), and it is logical that it was effective against another platyhelminth worm; however, the cyst wall might slow down transmission of the drug to the parasite, explaining why 2 injections were necessary to stop the infection.

Acknowledgements. The fish were collected under a permit from Province Sud, New Caledonia. C. Dupoux, IRD, helped in the parasitological investigation, and C. Cazier, UQ, prepared the histological sections.

\section{LITERATURE CITED}

Cannon LRG (1986) Turbellaria of the world. Queensland Museum, Brisbane

Cannon LRG, Lester RJG (1988) Two turbellarians parasitic in fish. Dis Aquat Org 5:15-22

Crespo González C, Reza Álvarez RM, Rodríguez Dominguez $\mathrm{H}$, Soto Búa M, Iglesias R, Arias Fernández C, García Estévez JM (2005) In vitro reproduction of the turbellarian Urastoma cyprinae isolated from Mytilus galloprovincialis. Mar Biol 147:755-760

Editorial responsibility: David Marcogliese, Montreal, Québec, Canada
Fajer-Avila EJ, Velasquez-Medina SP, Betancourt-Lozano M (2007) Effectiveness of treatments against eggs, and adults of Haliotrema sp. and Euryhaliotrema sp. (Monogenea: Ancyrocephalinae) infecting red snapper, Lutjanus guttatus. Aquaculture 264:66-72

Grutter AS (1994) Spatial and temporal variations of the ectoparasites of seven reef fish species from Lizard Island and Heron Island, Australia. Mar Ecol Prog Ser 115:21-30

Justine JL (2007) Fish parasites: Platyhelminthes (Monogenea, Digenea, Cestoda) and nematodes, reported from off New Caledonia. In: Payri CE, Richer de Forges B (eds) Compendium of marine species from New Caledonia. Documents Scientifiques et Techniques II7, 2nd edn. Institut de Recherche pour le Développement, Nouméa, p 183-198

Kent ML (1981) The life cycle and treatment of a turbellarian disease of marine fishes. Freshw Mar Aquar 4:11-13

Kent ML, Olson AC (1986) Interrelationships of a parasitic turbellarian (Paravortex sp.) (Graffillidae, Rhabdocoela) and its marine fish hosts. Fish Pathol 21:65-72

Lockyer AE, Olson PD, Littlewood DTJ (2003) Utility of complete large and small subunit rRNA genes in resolving the phylogeny of the Neodermata (Platyhelminthes): implications and a review of the cercomer theory. Biol J Linn Soc 78:155-171

Menitskii YL (1963) Structure and systematic position of the turbellarian Ichthyophaga subcutanea Syromjatnikova 1949, parasitising fish. Parazitol Sb 21:245-258 (in Russian)

Möller H, Anders K (1986) Diseases and parasites of marine fishes. Verlag Möller, Kiel

Ondrackova M, Bartosova S, Valova Z, Jurajda P, Gelnar M (2004) Occurrence of black-spot disease caused by metacercariae of Posthodiplostomum cuticola among juvenile fishes in water bodies in the Morava River basin. Acta Parasitol 49:222-227

Quist MC, Bower MR, Hubert WA (2007) Infection by a black spot-causing species of Uvulifer and associated opercular alterations in fishes from a high-desert stream in Wyoming. Dis Aquat Org 78:129-136

> Schmahl G, Mehlhorn H (1985) Treatment of fish parasites. 1. Praziquantel effective against Monogenea (Dactylogyrus vastator, Dactylogyrus extensus, Diplozoon paradoxum). Z Parasitenkd Parasitol Res 71:727-737

Shukhgalter O, Chukalova N (2002) An investigation of 'black spot' disease of bream (Abramis brama) from the Curonian Lagoon, south-eastern Baltic Sea. Bull Eur Assoc Fish Pathol 22:218-221

Sluys R, Kawakatsu M (2005) A replacement name for Ichthyophaga Syromiatnikova, 1949 (Platyhelminthes: Prolecithophora), with a nomenclatural analysis of its avian senior homonym. Species Divers 10:63-68

Syromiatnikova IP (1949) A new turbellarian parasitic in fish and called Ichthyophaga subcutanea. Dokl Akad Nauk SSSR 68:805-808 (in Russian)

Williams RE, Ernst I, Chambers CB, Whittington ID (2007) Efficacy of orally administered praziquantel against Zeuxapta seriolae and Benedenia seriolae (Monogenea) in yellowtail kingfish Seriola lalandi. Dis Aquat Org 77: 199-205

Submitted: February 19, 2009; Accepted: April 29, 2009

Proofs received from author(s): June 22, 2009 